\title{
Risk Management of Wastewater Treatment in the Wastewater Treatment Plant of PT. X
}

\author{
Fauziah Raya Shinta $^{1}$, Nieke Karnaningroem ${ }^{1}$ and Mas Agus Mardyanto ${ }^{1}$
}

\begin{abstract}
The economic rise as much as $5.5 \%$ in East Java region in the first quarter of 2018 compared to the first quarter of 2017, was due to the main supporting factor of an increase in the number of industries. An increase in industry has the potential to cause environmental pollution, especially in water bodies as evidenced by an index of water quality conditions for East Java rivers that now stands on Class II. Currently, PT. X in East Java is working on the expansion of its company. This study aims to identify the risks of wastewater treatment of PT. X using the fishbone analysis method and determine the priority of failures that must be handled using the FMEA method.For research purposes, two types of data are used, namely secondary and primary data. Secondary data includes flow chart of wastewater treatment, wastewater quality report and standard operating procedures. Meanwhile, the primary data for the quality of wastewater treatment was obtained through sampling, which was carried out at each wastewater treatment unit as well as the results of questionnaire with direct interviews. From those two types of data, an analysis of the potential occurrence of risk arises by using a fishbone analysis diagram. The risk results obtained through fishbone analysis are then processed using the Failure Mode and Effects Analysis (FMEA) method to obtain a Risk Priority Number (RPN). Then, the results of risk analysis from fishbone analysis are assessed into a priority of failures, expressed in Risk Priority Number (RPN).Based on the analysis of research data, it was concluded that the problem that occurred in wastewater treatment was inefficient wastewater treatment. The inefficient process was caused by the WWTP design conditions that were greater than the inlet discharge. Based on the results of data processing using the FMEA method, it was found that the largest RPN value was 125.
\end{abstract}

Keywords-Industrial Wastewater, Risk Analysis, Fishbone Analysis, FMEA, Industrial Area.

\section{INTRODUCTION}

According to the Badan Pusat Statistika (BPS) East Java, in the first quarter of 2018 East Java Province tended to experience an increase in the economy sector. The increase in the economy of the province of East Java in the first quarter of 2018 was 5.5\% compared to the previous year. The economic increase was mainly supported by industrial growth in the East Java region which was also quite high. Industrial growth, of course, besides having a positive

\footnotetext{
${ }^{1}$ Fauziah Raya Shinta, Nieke Karnaningroem and Mas Agus Mardyanto are with Department of Environmental Engineering, Institut Teknologi Sepuluh Nopember, Surabaya, Indonesia, 60111, Indonesia. Email:_rayashinta5@gmail.com; nieke@enviro.its.ac.id; mardyanto@enviro.its.ac.id.
}

impact, also has a bad impact. This happened because industrial growth was also accompanied by an increase in the quantity of waste water produced by these activities. based on the Department of Environment in 2016, river water quality in East Java Province has decreased. The East Java province water index in 2016 was 50.7. This index shows that the quality of the East Java river is below class II, with conditions not suitable for consumption. This happens along with increasing human activity, both in terms of industry and domestic or household. In this case it means that there needs to be a significant improvement in waste water management. Because wastewater carries a variety of substances in it that have the potential to endanger health.

Wastewater must be treated before being discharged into the water body freely, because the ingredients contained in waste water can cause a decrease in water quality. Pollution is something that is very common around us today, one of which is caused by industrial growth. This decrease in water quality is caused by the inability of the whole water body to continue to accommodate the waste that continues to enter into it every day. Overall, the river is polluted with hazardous materials from waste water due to waste water disposal activities that do not receive good supervision. Own waste water contains compounds that can be toxic to the human body. Therefore, before being discharged into the liquid waste environment, the industrial process must be processed first. So that in dealing with these problems the Government of East Java forms an industrial area, this method is expected by the government to reduce the negative impact of increasing industry. Therefore, the East Java government made special regulations regarding the quality of effluent from wastewater that came out of each industry, namely the East Java Governor Regulation No.72 of 2013.

PT. X has operated a Waste Water Treatment Plant (WWTP) for 20 years to manage industrial wastewater. PT. $\mathrm{X}$ is fully committed to maintaining environmental quality by controlling the industry.

According to the company's development plan, in the near future PT. X will develop its industry. This increase certainly also requires special attention because it certainly will also cause an increase in the amount of waste water produced by the company.

This increase will certainly have an impact on the performance of WWTPs. This can pose risks in the future. Therefore, we need a system that can prevent problems. 
One way to prevent it is to use a risk management system, namely Failure Mode Effects and Analysis (FMEA).

According to Andiyanto, FMEA is one method of risk analysis used to evaluate the possibility of a failure of a system, process, design, or service. The failure is then quantified to determine the priority of handling. Risk is very likely to arise in every process because all processes must produce waste or waste that is actually not desirable. This waste or waste can cause a risk. FMEA is the right method to use because FMEA is able to determine priorities in handling problems, besides that FMEA is also a method that is able to analyze problems thoroughly.

So that in this study the aim was to manage the risk of wastewater tseatment at PT. X. For this reason, a risk analysis of wastewater treatment is carried out by using fishbone analysis, then the priority for handling failure is determined using the FMEA method

\section{LITERATURE REVIEW}

\section{A. Wastewater}

Waste water can come from domestic and non-domestic activities. Domestic wastewater is water that comes from daily activities such as bathing, toilet water, washing clothes, etc. Some sources of commercial or nondomestic wastewater are salons, wood mills, or other commercial activities. According to the profile page Institute of Agriculture and Natural Resources accessed in 2018 in November, wastewater contains 99\% of water and $1 \%$ is an additional ingredient that needs to be considered because it can cause danger.

Waste water that is directly discharged into the environment can cause environmental pollution, especially aquatic ecosystems. High temperatures in wastewater can cause Dissolved Oxygen (DO) in wastewater to decrease dramatically so that it can cause the death of aquatic organisms. In addition to decreasing DO there will be an increase in nitrogen into nitrate compounds which can cause foul odor. In a certain period of time the waste water will change color to blackish brown which causes odor and can disturb human health. So that before being discharged into the water body, it is necessary to do processing for wastewater before being disposed of freely into the water body because it can disrupt public health

Therefore, wastewater needs our attention because water is a basic necessity for humans to carry out their lives. Most of the causes of the disease are from water, according to WHO data in 2002 alone $80 \%$ of the disease was caused by poor water quality due to microbiological contamination[1].

To address the problem of wastewater, the provincial government of East Java established a special regulation in East Java. Quality standards have been established and needs to be monitored. Determination of monitoring of own wastewater is determined based on the type of business carried out. Based on East Java Governor
Regulation no. 72 of 2013 describes the waste water quality standards as follows:

TABLE 1.

WASTE WATER QUALITY STANDARDS OF INDUSTRIAL ESTATES

\begin{tabular}{clcc}
\hline \hline No. & \multicolumn{1}{c}{ Parameter } & Unit & Maximum Level \\
\hline 1 & $\mathrm{pH}$ & $\mathrm{mg} / \mathrm{L}$ & $6.0-9.0$ \\
2 & TSS & $\mathrm{mg} / \mathrm{L}$ & 150 \\
3 & BOD & $\mathrm{mg} / \mathrm{L}$ & 50 \\
4 & COD & $\mathrm{mg} / \mathrm{L}$ & 100 \\
5 & Sulfide $\left(\mathrm{H}_{2} \mathrm{~S}\right)$ & $\mathrm{mg} / \mathrm{L}$ & 1 \\
6 & Free Ammonia $\left(\mathrm{NH}_{3}-\mathrm{N}\right)$ & $\mathrm{mg} / \mathrm{L}$ & 20 \\
7 & Phenol & $\mathrm{mg} / \mathrm{L}$ & 1 \\
8 & Oil and fat & $\mathrm{mg} / \mathrm{L}$ & 15 \\
9 & Detergent an ionic(MBAS) & $\mathrm{mg} / \mathrm{L}$ & 10 \\
10 & Cadmium & $\mathrm{mg} / \mathrm{L}$ & 0.1 \\
11 & Hexavalent chromium(Cr ${ }^{6+}$ & $\mathrm{mg} / \mathrm{L}$ & 0.5 \\
12 & Total chrome (Cr) & $\mathrm{mg} / \mathrm{L}$ & 1 \\
13 & Copper (Cu) & $\mathrm{mg} / \mathrm{L}$ & 2 \\
14 & Lead (Pb) & $\mathrm{mg} / \mathrm{L}$ & 1 \\
15 & Nickel (Ni) & $\mathrm{mg} / \mathrm{L}$ & 0.5 \\
16 & Zinc (Zn) & $\mathrm{mg} / \mathrm{L}$ & 10 \\
17 & Maximum waste & water & 0.8 L per second per Ha of \\
& volume & Industrial Estate land \\
\hline \hline
\end{tabular}

\section{B. Risk Management}

Risk is a state of uncertainty. Risk is something that causes loss if it occurs. Losses experienced are a process of uncertainty that results from risk, so that it must be managed effectively so that losses can be reduced. This management is aimed at the efficiency of the processes carried out to achieve a goal[2].

Risk management is a very important process. Own risk management is used for pre-analysis, predicting, and controlling risk. In addition, risk management also serves to reduce the risks that might be caused. Therefore, risk management is needed to reduce the possibility of failure and can provide convenience for handling risks that might arise.

In particular environmental risk management is a systematic process used to determine environmental hazards, analyze possibilities, consequences, and regulate the outcome of the risk level. According to [3] environmental risk management is carried out in four stages, namely:

\section{1) Problem Formulation}

Is the initial stage of the process for evaluation of a condition that occurs or may occur from the activities carried out. In the formulation of the problems that are used include: identifying and describing problems, m collecting and integrating available information, and developing a risk analysis plan. 


\section{2) Risk Analysis}

An emerging risk can be measured using the consequences and the probability (likelihood). Likelihood is a possibility that can occur based on the frequency of occurrence.

3) Risk Characterization

Risk characterization is the final step where the level of risk is determined based on the risk assessment that has been carried out at risk analysis.

\section{4) Risk Management}

Risk management is a stage to consider alternative strategies that can be done to reduce or eliminate risks that may or have arisen. This stage is also referred to as the risk mitigation stage. Risk mitigation is carried out to eliminate or reduce the likelihood of the consequences of long-term risk reduction actions. At this stage, identification of risks, hazards that can occur, how hazards occur, and estimation of risk levels and risk priorities are determined.

\section{Fishbone Analysis}

Fishbone analysis or also known as a causal diagram is one of the types of methods of using Root Causes Analysis (RCA). Fishbone analysis is a more complex method compared to other RCA methods. Because fishbone analysis contains potential problems that may exist and also causes them in detail [4]. According to Wicaksono the benefits of using fishbone analysis are:

1. Clarify the causes of a problem or problem.

2. Can use real conditions for the purpose of improving the quality of products or services, more efficient in the use of resources, and can reduce cost.

3. Can reduce and eliminate conditions that cause product or service mismatches and complaints customer.

4. Can make a standardization of existing and planned operations.

5. Can provide education and training for employees in decision making and action activities repair.

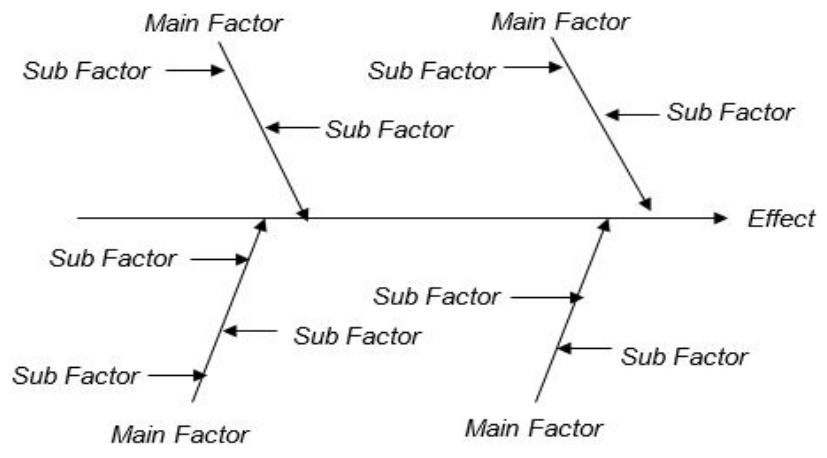

Picture 1. Fishbone analysis diagram

\section{Failure Mode and Effect Analysis}

Failure Mode and Effects Analysis (FMEA) is an analytical technique that combines technology and experience in identifying production process failures and plans to prevent them from happening again. The advantage of the FMEA method is to ensure the final product is in accordance with the specifications, helps to identify and eliminate or control the way the failure is dangerous, and improve reliability. According to Agusta FMEA has a goal, namely:

a. Know and predict potential failures of products or processes that can occur.

b. Predict and evaluate the effect of failure on functions in the existing system.

c. Showing priority on improving a process or subsystem through a list of process improvements or subsystems that must be improved.

d. Identify and build corrective actions that can be taken to prevent or reduce the chance of potential failure or influence on the system.

e. Document the whole process

According to Waghmare in the implementation of FMEA it is able to process identification of possible shortcomings that occur in products, systems, designs, or processes.

The numerical measurement used is then referred to as Risk Priority Number (RPN). Determination of RPN assessment is by multiplication of Severity (S), Occurance (O), and Detection (D) can be seen in equation 1 . In its measurement FMEA uses ratings in all three aspects. Scale determination is based on literature studies and potential failure mode. According to Sari, RPN is a value that states the highest risk and corrective action to be taken, the higher the value of the RPN means the more corrective action must be taken immediately to prevent this from happening.

$$
\mathrm{RPN}=(\mathrm{S}) \times(\mathrm{O}) \times(\mathrm{D})
$$

Severity is intended to determine failures that arise based on the requirements of their functions and effects. The intended failure is a failure that makes it possible to trigger another failure, so that any failure that occurs must be recorded in technical terms so that it can be used as data. Every effect that appears will be given a number from 110 , the number represents a failure condition that appears from harmless to very dangerous. Determination of the severity assessment is based on conditions that exist in the field related to failures that can occur during a process. So that risk assessment and severity criteria can be adjusted to the needs and conditions based on the process being analyzed.

Occurance in this analysis states how often (frequency) the occurrence of the failure arises. In this aspect it is important to know the cause of failure that arises. This can be done by looking at old documents related to the same events that have happened to the product or process that caused the failure.

Detection is a measurement of the ability to control or control an event that occurs. Detection values are based on the technology used in handling failures that arise. From this control, the technician can find out how often failures are identified or detected. Each combination of the 
previous two steps gets a detection number (D). This ranks the capabilities of planned tests and inspections to eliminate defects and detect mode failures at certain times.

\section{METHODOLOGY}

\section{A. Data Acquisition}

Data collection is carried out to support further analysis that will be carried out in research so that research can be in accordance with stated objectives. The data needed in the study is divided into primary data and secondary data.

Primary data in this study is data that is directly obtained through activities carried out during the study. The primary data intended in this case is data on the quality of wastewater treated in each processing unit and the results of interviews through questionnaires related to wastewater treatment carried out. Primary data collection is done by sampling each unit, laboratory analysis, and cake.

Sampling of wastewater was carried out in each unit using the grab sampling method. WWTP uses 5 units for processing the wastewater. The processing unit used is the first settling tank that also functions as an equalization tank (the first settling basin), grit chamber, primary settling tank, oxidation ditch, and final clarifier. In this study the unit samples to be taken are 5 units, namely the first settling tank, grit chamber, primary settling tank, oxidation ditch, and final clarifier. Sampling was not done in distribution boxes I and II because there was no processing in the two units, both of which functioned as speed dividers or discharge before entering the next unit. The following is a diagram of the wastewater treatment diagram and the sampling point that will be carried out:

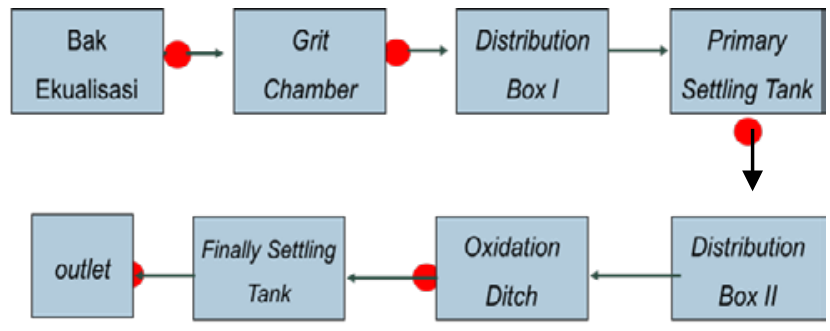

Figure 2. Sampling point for Wastewater

The questionnaire used in this case is to use the interview method directly to policy holders regarding wastewater treatment and wastewater treatment operators. The cake used is asking about the operating conditions of the WWTP. In the operation of the WWTP, the condition and operation of each unit is needed as well as understanding and knowledge of the human resources involved in processing WWTPs.

\section{B. Problem Analysis}

In this process all data, both secondary and primary, are used related to wastewater treatment (interviews and analysis of wastewater quality). Risk analysis is carried out by daily observations in the field related to the technical treatment in wastewater treatment and the entire process that occurs within it. The following are steps that can be taken to simplify the risk analysis:

1. Understand the waste water treatment process.

2. Analyzing the risk of failure that might arise in wastewater treatment refers to the standards that should apply.

3. Determine the main cause of wastewater treatment failure.

4. Then determine the greatest effect that can be caused by known risks

Problem identification is done using fishbone analysis by looking at 2 aspects, namely as follows:

5) Human Resources

Is a factor that is used to find out the knowledge of the manager or practitioner.

6) Technical

Is the type of unit used in WWTP, problems that have arisen, designs used for WWTP, and maintenance carried out on units and instruments of WWTP.

\section{Risk Identification}

Based on the results of the fishbone analysis carried out so as to produce risk then an analysis of the causes of the risk is carried out using the FMEA method. In use the FMEA method is done by assessing through three things: the severity (S), occurance (O), and detect (D).

\section{Risk Assasment}

Risk assessment is carried out based on the values obtained through the risk identification stage, after risk identification is carried out, then it is seen how much risk is occurring, and then the handling of the riots is analyzed or not. Risk assessment is also referred to as Risk Priority Number (RPN), the assessment is obtained from the making of weighting based on the value of Severity, Occurance, and Detection making the weighting of the risk assessment based on the results of the initial description of the research location. The RPN is used to state the level of risk that requires first handling, so it can be said that the RPN is used to determine the priority of handling problems.

\section{RESUlt AND DISCUSSION}

In the Waste Water Treatment Plant of PT. X there are 5 types of units, namely the first settling tank, grit chamber, secondary settling tank, oxidation ditch, and final settling tank. The average debit of WWTP in PT.X daily is 4100 $\mathrm{m} /$ second. For each unit has a different number, the details of the number of units can be seen in the following table.

TABEL 2.

UNIT OF WWTP

\begin{tabular}{lcc}
\hline \hline Unit Type & Number of units & Volume of each unit \\
\hline The first settler & 1 & $465.6 \mathrm{~m}^{3}$ \\
Grit Chamber & 2 & $16,938 \mathrm{~m}^{3}$
\end{tabular}




\begin{tabular}{lcc}
\hline \hline \multicolumn{1}{c}{ Unit Type } & Number of units & Volume of each unit \\
\hline $\begin{array}{l}\text { Secondary Settling } \\
\text { Tank }\end{array}$ & 1 & $658,085 \mathrm{~m}^{3}$ \\
Oxidation ditch & 4 & $3274.84 \mathrm{~m}^{3}$ \\
Final settling tank & 2 & $1540 \mathrm{~m}^{3}$ \\
\hline \hline
\end{tabular}

The functions of the WWTP units in the PT.X WWTP are then reviewed in terms of their initial implementation and design. Comparison with the initial design aims to determine the suitability of the operations that have been there with real conditions. In addition to the operating units in the implementation of WWTP, it is also necessary to evaluate human resources that carry out operations. The operation of WWTP is viewed from the understanding of the units operated and the understanding of the supporting regulations of the WWTP itself.

\section{A. Standar Design of WWTPs}

Based on the unit design standards compared to [5] the results are as follows:

\section{1) Primary Settling Tank}

Primary Settling tank has a functions to precipitate suspended solids in wastewater, deposition in the first settling tank using gravity (specific gravity of suspended solids

Hydrolic Retention Time (HRT) for the first sedimentation unit is 3.16 hours. This is due to the WWTP inlet discharge still not meeting the established WWTP design standards. Based on calculations from HRT, settling can still accommodate a maximum of $7,449 \mathrm{~m}^{3} /$ day, while the minimum discharge required to meet the WWTP design standards is $4469,7 \mathrm{~m}^{3} /$ day.

The current of OFR value based on the daily average discharge is $17.65 \mathrm{~m}^{3} / \mathrm{m}^{2}$ days, while the peak discharge OFR value is $21.487 \mathrm{~m}^{3} / \mathrm{m}^{2}$ days. Both of these parameters do not meet the ad standard design. The value of OFR and HRT influence each other, if the OFR and HRT values are quite low, it means that the conditions of the efficiency of the deposition process are good, but if both of these values are too low, septic conditions can occur[6].

Obtained the calculation result of NRe value for the first settling tub is 6376, the Nfr value for the existing condition is $5,042 \times 10^{-8}$. Both of these in the first settling tank do not meet design standards. Based on the amount of NRe value, the flow pattern in the first sedimentary unit can be categorized as having a turbulent flow[7]. The NRe and Nfr values describe the flow pattern from the settling basin, so that when the turbulent flow and the froude number value the precipitation will not be maximal.

TABLE 3. SEDIMENTARY DESIGN[5].

\begin{tabular}{lll}
\hline \multicolumn{1}{c}{ Parameter } & Range & \multicolumn{1}{c}{ Unit } \\
\hline Hydarulic Retention Time (HRT) & $1.5-2.5$ & Hour \\
Average flow overflow rate & $25-30$ & $\mathrm{~m}^{3} / \mathrm{m}^{2}$ days \\
Peak flow overflow rate & $50-70$ & $\mathrm{~m}^{3} / \mathrm{m}^{2}$ days \\
\hline \hline
\end{tabular}

\begin{tabular}{llll}
\hline \hline & Parameter & Range & Unit \\
\hline NRe & $<2000$ & - \\
Nfr & $>^{10-5}$ & - \\
\hline \hline
\end{tabular}

2) Grit chamber

Grit chamber is a unit that serves to reduce, eliminate, or precipitate grit particles, so that the particles do not clog the channel or damage the pump WWTP uses a horizontal flow grit chamber grit chamber tip.

Based on these calculations it is known that the residence time on the grit unit is 14 minutes. Therefore, for now the residence time of the grit chamber unit does not meet the standard because of the lack of discharge. The calculation results that the value of horizontal speed is $0.016 \mathrm{~m} / \mathrm{s}$, meaning that the horizontal speed is less than the design standard.

TABLE 4.

STANDARD CHAMBER GRIT UNIT[5]

\begin{tabular}{lll}
\hline \hline Parameter & Range & Unit \\
\hline HRT & $45-90$ & Seconds \\
Vh & $0.8-1.3$ & $\mathrm{~m} / \mathrm{s}$ \\
\hline \hline
\end{tabular}

\section{3) Secondary settling tank}

In the implementation of the secondary field settling tanks contained in the processing unit serves to precipitate suspended particles that have not been fully deposited in the first settling tank. The secondary tank set unit has a circular shape.

The calculation results obtained that HRT for the secondary unit a tank settling is 4.4 hours, which means it exceeds the design standard. This is due to the WWTP inlet discharge still not meeting the established WWTP design standards. Based on calculations from HRT the settler can still accommodate a maximum of $10,529 \mathrm{~m}^{3} / \mathrm{day}$, while the minimum discharge required to meet the WWTP design standard is $6317,7 \mathrm{~m}^{3} /$ day.

From these calculations it was found that the OFR for peak discharge and average was less than the predetermined design standard. The OFR value itself represents the speed of a suspended particle to settle the current OFR value based on the daily average discharge of $10.19 \mathrm{~m}^{3} / \mathrm{m}^{2}$ days, while the peak discharge of the OFR value is $16.13 \mathrm{~m}^{3} / \mathrm{m}^{2}$ days. Both of these parameters do not meet the existing design standards, this is because the discharge in the secondary unit settling tank is still less than the design standard. So that until the unit meets the minimum discharge the OFR value will always be below the standard. Low OFR and HRT values indicate that the secondary settling tank is still able to accommodate waste water.

TABLE 5

STANDARD SECONDARY SETTLING TANK DESIGN[5]

\begin{tabular}{lccc}
\hline & Parameter & Range & Unit \\
\hline HRT & $1.5-2.5$ & Hour \\
\hline \hline
\end{tabular}


The $1^{\text {st }}$ International Conference on Business and Management of Technology (IConBMT)

August 3rd 2019, Institut Teknologi Sepuluh Nopember, Surabaya, Indonesia

\begin{tabular}{llc}
\hline \multicolumn{1}{c}{ Parameter } & \multicolumn{1}{c}{ Range } & \multicolumn{1}{c}{ Unit } \\
\hline Average flow overflow rate & $30-50$ & $\mathrm{~m}^{3} / \mathrm{m}^{2}$ days \\
Peak flow overflow rate & $80-120$ & $\mathrm{~m}^{3} / \mathrm{m}^{2}$ days \\
\hline \hline
\end{tabular}

4) Oxidation ditch

Oxidation ditch is a development of activated sludge system. Oxidation is exploited by microorganisms in carrying out the process, waste water which is in the ditch oxidation unit will then experience contact with the air with the help of the rotor so that the aeration process occurs in the wastewater[8].

The calculation results found that HRT for the ditch oxidation unit is 44 hours, which means it exceeds the design standard. This is due to the WWTP inlet discharge still not meeting the established WWTP design standards.

Based on the calculation results it can be seen that the BOD loading rate is $0.244 \mathrm{~kg} \mathrm{BOD} / \mathrm{m}^{3}$ days. Based on these conditions, the BOD loading rate still meets the design criteria and is in a condition that tends to be safe because it has a considerable distance with the maximum working power of oxidation ditch. Based on the data obtained the value of MLSS in the processing unit ranged from 4000-5000 mg/L. The MLSS and F / M ratios will be directly proportional[9].

TABLE 6.

STANDARDIZED OXIDATION DESIG[5], [8]

\begin{tabular}{|c|c|c|}
\hline Parameter & Range & Unit \\
\hline HRT & $18-36$ & Hour \\
\hline BOD load * & $0.1-0.6$ & $\mathrm{Kg}$ BOD $/ \mathrm{m}^{3}$. Days \\
\hline MLSS * & $3000-6000$ & $\mathrm{mg} / \mathrm{L}$ \\
\hline $\mathbf{F} / \mathbf{M}$ & $0,04-0,1$ & Kg BOD / kg MLSS.d \\
\hline
\end{tabular}

\section{5) Final settling tank}

The final settling tank serves to deposit floc which has been formed from the ditch oxidation process. When in the endogenous phase of deposition, it will be more maximal because energy and microbial growth are limited. Factors that cause precipitation in the final maximum settling tank when the $\mathrm{F} / \mathrm{M}$ ratio is low.

The calculation results obtained show that HRT for the final settling tank is 20 hours, which means it exceeds the design standard.

The current OFR value based on the daily average discharge is $2,86 \mathrm{~m}^{3} / \mathrm{m}^{2}$ days, while the peak discharge OFR value is $9.07 \mathrm{~m}^{3} / \mathrm{m}^{2}$. Both of these parameters do not meet the existing design standards, this is because the discharge in the final unit of the tank settling is still less than the design standard.

TABLE 7.

FINAL DESIGN STANDARDS FOR SETTLING TANKS[5]

\begin{tabular}{lll}
\hline \hline Parameter & Range & Unit \\
\hline HRT & $1.5-2.5$ & Hour \\
Average flow overflow rate & $24-32$ & $\mathrm{~m}^{3} / \mathrm{m}^{2}$ days \\
Peak flow overflow rate & $40-64$ & $\mathrm{~m}^{3} / \mathrm{m}^{2}$ days \\
\hline \hline
\end{tabular}

\section{B. Quality of Wastewater}

Data obtained from quality analysis results through sampling that has been done and daily quality test data from PT. X. Based on the data obtained through this is the condition obtained that there is a fluctuation in the concentration of wastewater. In this data it can be seen that the condition of the wastewater concentration is very volatile. So that in certain conditions the incoming wastewater requires different processing because the load of entry is different.

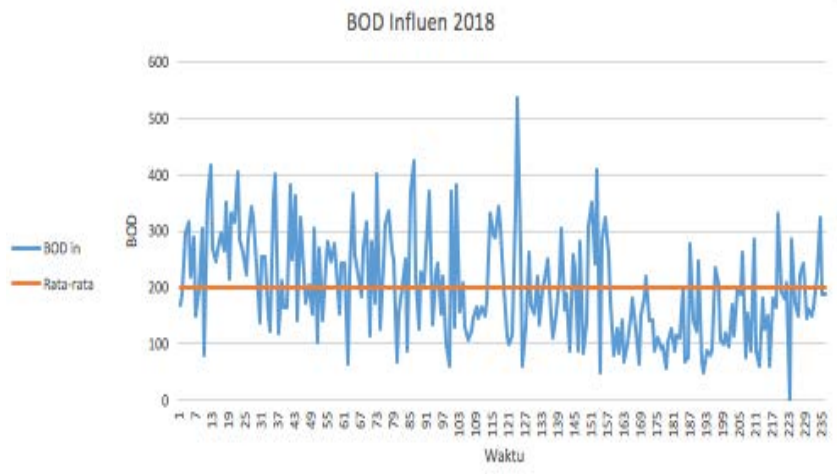

Figure 3. BOD influent charts during 2018

From the analysis result of daily quality in a year, it can conclude that there is much of the parameter of wastewater that still not qualified to the government regulation. The fluctuations of the inlet parameter is one of the causes. Than there must be a different treatment for a different condition.

From the results of daily one-year quality analysis from PT. $X$ it is known that there are several parameters that are not in accordance with the regulations. This was triggered by the fluctuations. So that in certain conditions it actually requires additional treatment but no additions are given.

Quality testing on WWTP uses laboratory testing, so it takes a long time to find out the quality test results. In this condition it can pose a risk to the environment if the results of effluent from wastewater treatment cannot be monitored continuously.

\section{Risk Analysis}

Based on the discussion above, we can see some potential risks of process failure. To facilitate risk analysis carried out, fishbone analysis is used. Fishbone analysis functions as a tool used in brainstorming. Overall the risk of wastewater treatment in PT. X is as follows in figure 4.

Based on the results of the fishbone for human resources, it is known that risks can arise from understanding the functions of all operating units and understanding the rules of Governor of East Java No. 72 of 2013.

The overall technical risks arising from unit cleaning, sludge dewatering, unit performance based on the initial design, laboratory analysis results, daily records for each 
unit, maintenance of complementary equipment for each unit, and routine evaluation for each unit.

\section{Risk Identification}

Identify the risk of wastewater treatment based on the results of fishbone analysis. Fishbone analysis results will then identify risks that can occur. Based on the conditions above, risk factors can arise.

Determination of risk factors will be analyzed using three aspects that exist in FMEA, namely: severity, assurance, and detection. Determination of severity is based on the severity of a condition. Occurance is assessed based on the number of events that occur during one year. While for detection, it is identified based on the handling that has been done or existed for a period of one year.

\section{E. Risk Assessment}

After identifying the risk then the risk that arises is assessed based on the range that has been made in risk identification. The assessment carried out is adjusted to the field conditions while still using the reference for the use of existing assessments. Based on the

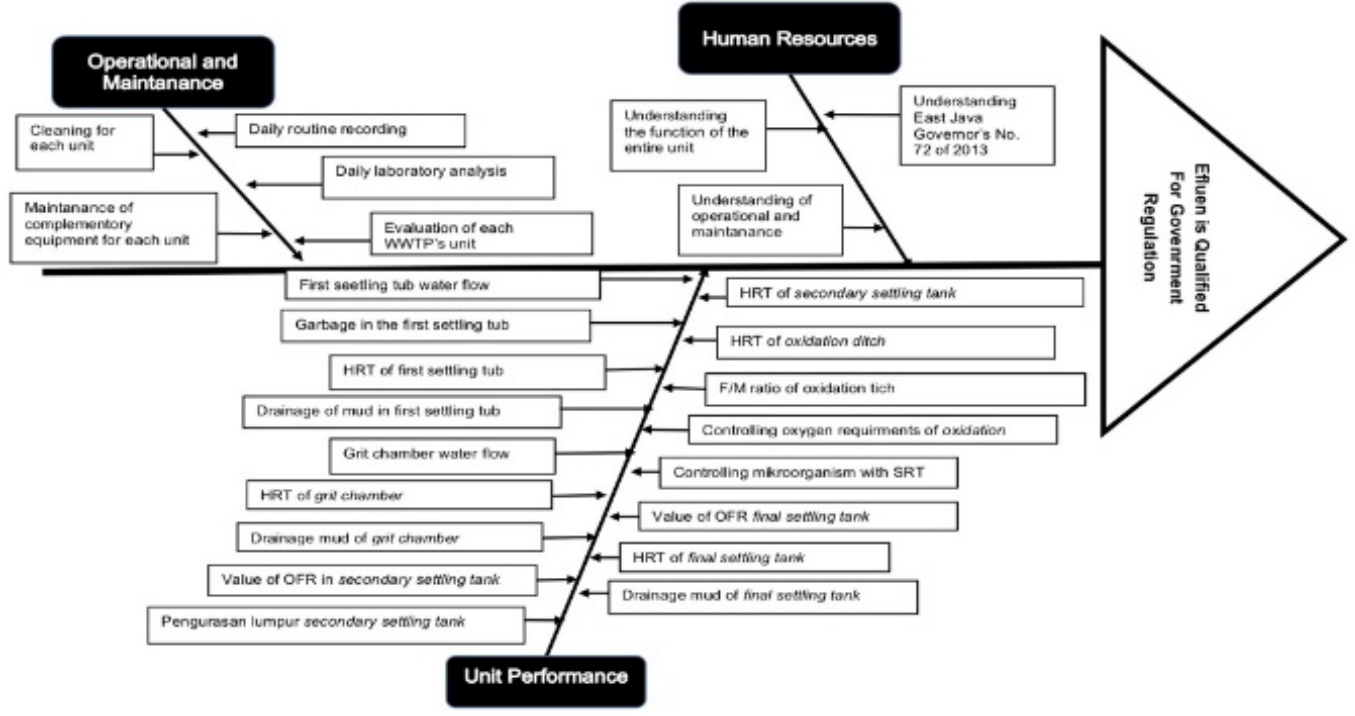

Figure 4. Fishbone Analysis of WWTP

TABLE 8.

FMEA WORKSEHEET

\begin{tabular}{|c|c|c|c|c|c|c|c|c|c|c|}
\hline \multicolumn{2}{|c|}{ Aspec } & \multirow{2}{*}{\begin{tabular}{l}
\multicolumn{1}{c}{ Failure } \\
Understanding of \\
East Java \\
Governor's \\
Regulation \\
No. 72 of 2013 \\
\end{tabular}} & \multirow{2}{*}{$\begin{array}{l}\text { Effect of failure } \\
\text { The control over } \\
\text { the running } \\
\text { process of WWTP } \\
\text { is not optimal }\end{array}$} & \multirow{2}{*}{$\begin{array}{l}\mathrm{S} \\
3 \\
\end{array}$} & \multirow{2}{*}{\begin{tabular}{l}
\multicolumn{1}{c}{$\begin{array}{c}\text { Potential failure/ } \\
\text { mechanism of failure }\end{array}$} \\
Lack of training for field \\
operators to discuss the \\
overall operation of WWTP \\
in terms of applicable \\
regulations
\end{tabular}} & \multirow{2}{*}{$\begin{array}{l}\mathbf{0} \\
5\end{array}$} & \multirow{2}{*}{\begin{tabular}{|l|}
\multicolumn{1}{|c|}{ Current control } \\
Regulatory documents \\
owned by the office and \\
also monthly controls for \\
reports to the environmental \\
department \\
\end{tabular}} & \multirow[t]{2}{*}{$\mathbf{D}$} & \multirow{2}{*}{\begin{tabular}{|c|} 
RPN \\
75 \\
\end{tabular}} & \multirow{2}{*}{$\begin{array}{c}\text { Handling } \\
\text { Priority }\end{array}$} \\
\hline $\begin{array}{l}\text { Human } \\
\text { Resources }\end{array}$ & & & & & & & & & & \\
\hline & & $\begin{array}{l}\text { Understanding of } \\
\text { the Maintenance } \\
\text { and Operation of } \\
\text { WWTP }\end{array}$ & $\begin{array}{l}\text { The overall } \\
\text { process of } \\
\text { operation and } \\
\text { control of WWTP }\end{array}$ & 2 & $\begin{array}{l}\text { Lack of training for field } \\
\text { operators to discuss the } \\
\text { overall operation of WWTP } \\
\text { in terms of applicable } \\
\text { regulations }\end{array}$ & 5 & $\begin{array}{l}\text { Work Instruction for } \\
\text { WWTP operations on } \\
\text { several units }\end{array}$ & 5 & 50 & 11 \\
\hline & & $\begin{array}{l}\text { Insight into the } \\
\text { 'processing } \\
\text { technology used }\end{array}$ & $\begin{array}{l}\text { The overall } \\
\text { process of } \\
\text { operation and } \\
\text { control of WWTP }\end{array}$ & 3 & $\begin{array}{l}\text { Lack of training for field } \\
\text { operators discussing the } \\
\text { overall operation of } \\
\text { WWTPs }\end{array}$ & 5 & $\begin{array}{l}\text { Work Instruction for } \\
\text { WWTP operations on } \\
\text { several units }\end{array}$ & 5 & 75 & 8 \\
\hline \multirow[t]{3}{*}{$\begin{array}{l}\text { Unit } \\
\text { performance }\end{array}$} & $\begin{array}{l}\text { The first } \\
\text { settler }\end{array}$ & Overflow rate & $\begin{array}{l}\text { Precipitation that } \\
\text { runs is not optimal }\end{array}$ & 2 & $\begin{array}{l}\text { Solids that are supposed to } \\
\text { settle can be carried over to } \\
\text { the next process and can } \\
\text { form dead zones in certain } \\
\text { areas }\end{array}$ & 5 & No control has been taken & 5 & 50 & 17 \\
\hline & & Nre turbulent & $\begin{array}{l}\text { Precipitation that } \\
\text { runs is not optimal }\end{array}$ & 5 & $\begin{array}{l}\text { Solids that are supposed to } \\
\text { settle can be carried over to } \\
\text { the next process }\end{array}$ & 5 & No control has been taken & 5 & 125 & 4 \\
\hline & & HRT & $\begin{array}{l}\text { The deposition } \\
\text { process is not } \\
\text { optimal or can }\end{array}$ & 2 & $\begin{array}{l}\text { Debit that is not in } \\
\text { accordance with the } \\
\text { planning discharge, so }\end{array}$ & 5 & No control has been taken & 5 & 50 & 16 \\
\hline
\end{tabular}


The $1^{\text {st }}$ International Conference on Business and Management of Technology (IConBMT)

August 3rd 2019, Institut Teknologi Sepuluh Nopember, Surabaya, Indonesia

\begin{tabular}{|c|c|c|c|c|c|c|c|c|c|}
\hline & & \begin{tabular}{l|} 
result in septic \\
conditions
\end{tabular} & & that idle capacity occurs & & & & & \\
\hline & Drainage of mud & $\begin{array}{l}\text { Interferes with the } \\
\text { deposition process } \\
\text { that occurs when } \\
\text { it exceeds the } \\
\text { designated mud } \\
\text { chamber } \\
\end{array}$ & 2 & $\begin{array}{l}\text { Drainage is carried out } \\
\text { beyond the capacity of the } \\
\text { sludge }\end{array}$ & 4 & $\begin{array}{l}\text { Drain is done every } 3 \\
\text { months }\end{array}$ & 4 & 32 & 19 \\
\hline & $\begin{array}{l}\text { Complementary } \\
\text { Equipment } \\
\text { (pumps) }\end{array}$ & \begin{tabular}{|l|} 
There are \\
obstacles in \\
draining mud \\
\end{tabular} & 3 & $\begin{array}{l}\text { Checking for sludge pumps } \\
\text { is not carried out regularly }\end{array}$ & 1 & $\begin{array}{l}\text { Checking is done but is not } \\
\text { regular }\end{array}$ & 2 & 6 & 29 \\
\hline & $\begin{array}{l}\text { Inlet conditions } \\
\text { have unexpected } \\
\text { waste or } \\
\text { contaminants }\end{array}$ & $\begin{array}{l}\text { The deposition } \\
\text { process is not } \\
\text { optimal because } \\
\text { there } \\
\text { are floating solids } \\
\end{array}$ & 4 & $\begin{array}{l}\text { There is no filter before the } \\
\text { water enters the WWTP } \\
\text { inlet }\end{array}$ & 5 & $\begin{array}{l}\text { Cleaned regularly every two } \\
\text { hours by the wastewater } \\
\text { operator }\end{array}$ & 5 & 100 & 7 \\
\hline $\begin{array}{l}\text { Grit } \\
\text { Chamber }\end{array}$ & Vh & $\begin{array}{l}\text { The deposition } \\
\text { process is not } \\
\text { optimal }\end{array}$ & 1 & $\begin{array}{l}\text { Solids that are supposed to } \\
\text { settle can be carried over to } \\
\text { the next process and can } \\
\text { form dead zones in certain } \\
\text { areas }\end{array}$ & 5 & No control has been taken & 5 & 25 & 22 \\
\hline & HRT & $\begin{array}{l}\text { The deposition } \\
\text { process is not } \\
\text { optimal }\end{array}$ & 2 & $\begin{array}{l}\text { Debit that is not in } \\
\text { accordance with the } \\
\text { planning discharge, so } \\
\text { that idle capacity occurs }\end{array}$ & 5 & No control has been taken & 5 & 50 & 18 \\
\hline & Drainage of mud & $\begin{array}{l}\text { Interferes with the } \\
\text { deposition process } \\
\text { that occurs when } \\
\text { it exceeds the } \\
\text { designated mud } \\
\text { chamber } \\
\end{array}$ & 1 & $\begin{array}{l}\text { Drainage is carried out } \\
\text { according to the } \\
\text { predetermined time limit }\end{array}$ & 1 & $\begin{array}{l}\text { Drain is done every } 3 \\
\text { months }\end{array}$ & 1 & 1 & 33 \\
\hline & $\begin{array}{l}\text { Complementary } \\
\text { equipment } \\
\text { (sluice) }\end{array}$ & $\begin{array}{l}\text { There are } \\
\text { obstacles in } \\
\text { controlling the } \\
\text { flow of incoming } \\
\text { water } \\
\end{array}$ & 5 & $\begin{array}{l}\text { Cannot control waste water } \\
\text { entering the chamber grit }\end{array}$ & 2 & no control has been taken & 3 & 30 & 20 \\
\hline $\begin{array}{l}\text { Secondary } \\
\text { Settling } \\
\text { Tank }\end{array}$ & Mud Pump & $\begin{array}{l}\text { There are } \\
\text { obstacles in } \\
\text { draining mud }\end{array}$ & 3 & $\begin{array}{l}\text { Checking for sludge pumps } \\
\text { is not carried out regularly }\end{array}$ & 1 & $\begin{array}{l}\text { Checking is done but is not } \\
\text { regular }\end{array}$ & 2 & 6 & 28 \\
\hline & Drainage of mud & $\begin{array}{l}\text { Sludge removal } \\
\text { will be hampered } \\
\text { if the mud pump } \\
\text { is damaged } \\
\text { because there is } \\
\text { no reserve }\end{array}$ & 3 & $\begin{array}{l}\text { Failure of the deposition } \\
\text { process because there is } \\
\text { carried mud }\end{array}$ & 1 & $\begin{array}{l}\text { Drain is done every three } \\
\text { months }\end{array}$ & 2 & 6 & 27 \\
\hline & Overflow rate & $\begin{array}{l}\text { Precipitation that } \\
\text { runs is not optimal }\end{array}$ & 2 & $\begin{array}{l}\text { Solids that are supposed to } \\
\text { settle can be carried over to } \\
\text { the next process and can } \\
\text { form dead zones in certain } \\
\text { areas }\end{array}$ & 5 & No control has been taken & 5 & 50 & 14 \\
\hline & HRT & $\begin{array}{l}\text { The deposition } \\
\text { process is not } \\
\text { optimal }\end{array}$ & 2 & $\begin{array}{l}\text { Debit that is not in } \\
\text { accordance with the } \\
\text { planning discharge, so } \\
\text { that idle capacity occurs } \\
\end{array}$ & 5 & No control has been taken & 5 & 50 & 15 \\
\hline & \begin{tabular}{|l|} 
Complementary \\
equipment \\
(scrapper)
\end{tabular} & $\begin{array}{l}\text { Precipitation that } \\
\text { runs is not optimal }\end{array}$ & 5 & $\begin{array}{l}\text { Scrapper damage to this } \\
\text { unit }\end{array}$ & 5 & No control has been taken & 5 & 125 & 3 \\
\hline $\begin{array}{l}\text { Oxidation } \\
\text { Ditch }\end{array}$ & HRT & $\begin{array}{l}\text { Rupture of floc } \\
\text { that has formed }\end{array}$ & 2 & Too long aeration time & 5 & No control has been taken & 5 & 50 & 12 \\
\hline & BOD load & $\begin{array}{l}\text { The aeration } \\
\text { process is not } \\
\text { optimal if the } \\
\text { incoming BOD } \\
\text { load is too high }\end{array}$ & 1 & $\begin{array}{l}\text { Control of incoming BOD } \\
\text { concentrations }\end{array}$ & 5 & No control has been taken & 5 & 25 & 21 \\
\hline & $\mathrm{F} / \mathrm{M}$ & $\begin{array}{l}\text { The effluent yield } \\
\text { did not meet the } \\
\text { desired target }\end{array}$ & 1 & $\begin{array}{l}\text { Check the condition of } \\
\text { bacteria }\end{array}$ & 1 & $\begin{array}{l}\text { Checking has been done } \\
\text { through the laboratory at } \\
\text { least once a week }\end{array}$ & 1 & 1 & 32 \\
\hline & Rotor care & $\begin{array}{l}\text { The aeration } \\
\text { process fails }\end{array}$ & 2 & $\begin{array}{l}\text { Rotor checking is done } \\
\text { every day }\end{array}$ & 1 & $\begin{array}{l}\text { Checking is done manually } \\
\text { by the operator. If you }\end{array}$ & 5 & 10 & 25 \\
\hline
\end{tabular}




\begin{tabular}{|c|c|c|c|c|c|c|c|c|c|c|}
\hline & & & & & & & $\begin{array}{l}\text { encounter obstacles, you } \\
\text { can add an aerator with a } \\
\text { floating aerator }\end{array}$ & & & \\
\hline & & Disolved Oxygen & $\begin{array}{l}\text { The aeration } \\
\text { process fails }\end{array}$ & 4 & $\begin{array}{l}\text { DO checking is done } \\
\text { manually, only one } \\
\text { operating unit has a DO } \\
\text { meter }\end{array}$ & 4 & $\begin{array}{l}\text { DO meter is found in only } \\
\text { one unit, besides manual } \\
\text { checking if it looks } \\
\text { problematic }\end{array}$ & 4 & 64 & 10 \\
\hline & & MLSS & $\begin{array}{l}\text { The effluent yield } \\
\text { did not meet the } \\
\text { desired target }\end{array}$ & 1 & $\begin{array}{l}\text { Checking wastewater } \\
\text { conditions }\end{array}$ & 1 & $\begin{array}{l}\text { Checking has been done } \\
\text { through the laboratory at } \\
\text { least once a week }\end{array}$ & 1 & 1 & 31 \\
\hline & $\begin{array}{l}\text { Final } \\
\text { settling } \\
\text { tank }\end{array}$ & Mud Pump & $\begin{array}{l}\text { There are } \\
\text { obstacles in } \\
\text { draining mud }\end{array}$ & 3 & $\begin{array}{l}\text { Checking for sludge pumps } \\
\text { is not carried out regularly }\end{array}$ & 1 & $\begin{array}{l}\text { Checking is done but is not } \\
\text { regular }\end{array}$ & 2 & 6 & 26 \\
\hline & & Overflow rate & $\begin{array}{l}\text { Precipitation that } \\
\text { runs is not optimal }\end{array}$ & 1 & $\begin{array}{l}\text { Solids that are supposed to } \\
\text { settle can be carried over to } \\
\text { the next process and can } \\
\text { form dead zones in certain } \\
\text { areas }\end{array}$ & 1 & No control has been taken & 5 & 5 & 30 \\
\hline & & HRT & $\begin{array}{l}\text { The deposition } \\
\text { process is not } \\
\text { optimal }\end{array}$ & 2 & $\begin{array}{l}\text { debit that is not in } \\
\text { accordance with the } \\
\text { planning debit, so that idle } \\
\text { capacity occurs }\end{array}$ & 5 & No control has been taken & 5 & 50 & 13 \\
\hline & & $\begin{array}{l}\text { Complementary } \\
\text { equipment } \\
\text { (scrapper) } \\
\end{array}$ & $\begin{array}{l}\text { Precipitation that } \\
\text { runs is not optimal }\end{array}$ & 2 & $\begin{array}{l}\text { Routine checking and } \\
\text { maintenance of scrapper }\end{array}$ & 3 & Check every once a week & 3 & 18 & 23 \\
\hline \multirow[t]{5}{*}{$\begin{array}{l}\text { Maintenance } \\
\text { and } \\
\text { Operation } \\
\end{array}$} & & Cleaning unit & $\begin{array}{l}\text { A process failure } \\
\text { occurred in the } \\
\text { next unit }\end{array}$ & 2 & $\begin{array}{l}\text { There are impurities in the } \\
\text { walls of the unit that are not } \\
\text { cleaned }\end{array}$ & 5 & $\begin{array}{l}\text { Observations made by the } \\
\text { operator in the final settling } \\
\text { tank }\end{array}$ & 1 & 10 & 24 \\
\hline & & $\begin{array}{l}\text { Unit Performance } \\
\text { Evaluation }\end{array}$ & $\begin{array}{l}\text { The effectiveness } \\
\text { and efficiency of } \\
\text { the unit's } \\
\text { performance } \\
\text { cannot be known } \\
\end{array}$ & 5 & $\begin{array}{l}\text { Evaluation in terms of } \\
\text { design standards was not } \\
\text { carried out }\end{array}$ & 5 & No control has been taken & 5 & 125 & 2 \\
\hline & & $\begin{array}{l}\text { Daily laboratory } \\
\text { analysis }\end{array}$ & $\begin{array}{l}\text { Control of the } \\
\text { results of the daily } \\
\text { WWTP mainly on } \\
\text { the condition of } \\
\text { the results of } \\
\text { wastewater } \\
\text { treatment is not } \\
\text { routinely } \\
\text { monitored }\end{array}$ & 4 & $\begin{array}{l}\text { Testing of influents and } \\
\text { effluent for wastewater is } \\
\text { not carried out routinely }\end{array}$ & 5 & No control has been taken & 5 & 100 & 6 \\
\hline & & Daily recording & $\begin{array}{l}\text { Daily control and } \\
\text { treatment data for } \\
\text { each unit is } \\
\text { incomplete }\end{array}$ & 5 & $\begin{array}{l}\text { Data related to daily } \\
\text { problems and effluents that } \\
\text { come out are not well } \\
\text { archived }\end{array}$ & 5 & $\begin{array}{l}\text { Daily data contained in the } \\
\text { operator's daily work report }\end{array}$ & 5 & 125 & 1 \\
\hline & & $\begin{array}{l}\text { Implementation } \\
\text { of SOP }\end{array}$ & $\begin{array}{l}\text { The wastewater } \\
\text { treatment process } \\
\text { will not be in } \\
\text { accordance with } \\
\text { the quality } \\
\text { standards and } \\
\text { several times there } \\
\text { are problems with } \\
\text { wastewater } \\
\text { treatment }\end{array}$ & 4 & $\begin{array}{l}\text { Uncontrolled SOP } \\
\text { implementation }\end{array}$ & 5 & There is an SOP & 5 & 100 & 5 \\
\hline
\end{tabular}

The table shows the risks that arise, the identification of risks, and the priority of handling carried out based on the FMEA method. The results of the RPN values obtained in the table can be seen that some have the same value. The same value is then sorted by handling based on the weighting previously.

Based on this condition, it can be seen in the problems that arise in the overall process is about incomplete daily records. Because the risk posed by incomplete and archived daily records is a later process failure. Process failure can arise because there is an increase or there are components that are no longer active, recording needs to be done to find out the history during WWTP operations.

In addition to risks arising from daily recording, the risks of operating and monitoring operations are the most common. One form of supervision that should be done is controlling the quality of output of waste water every day, while PT. X itself is only done on weekdays. This is due to 
The $1^{\text {st }}$ International Conference on Business and Management of Technology (IConBMT)

August 3rd 2019, Institut Teknologi Sepuluh Nopember, Surabaya, Indonesia

the absence of automatic tools that can be used and record results every day.

\section{CONCLUSION}

Based on these results can be known:

1. The main risk of PT. X wastewater treatment is on human resources and unit performance. Human resources in this case are knowledge and understanding regarding waste water operations and also regulations related to wastewater treatment. The risk is obtained from the results of discussion and analysis of data using the fishbone method.

2. The handling of the risk of wastewater treatment is emphasized on the value of the results of RPN 125, meaning that the problem with the value of the risk must be addressed first, especially regarding the handling of unit performance.

\section{ACKNOWLEDGMENT}

The author would like to thank Environmental Engineering Department of Institute Tekologi Sepuluh Nopember Surabaya for providing this study so that this research can be carried out properly.

\section{REFERENCE}

[1] I. O. Okonko, O. D. Adejoye, A. A. Ogun, A. A. Ogunjob, A. O. Nkang, and B. C. Adebayo-Tayo, "Hazards analysis critical control points (HACCP) and microbiology qualities of seafoods as affected by handlers hygience in Ibadan and Lagos, Nigeria,” African J. Food Sci., vol. 3, no. 2, pp. 35-50, 2009.

[2] A. Lokobal, M. D. J. Sumajouw, and B. F. Sompie, "Manajemen risiko pada perusahaan jasa pelaksana konstruksi di Propinsi Papua (study kasus di Kabupaten Sarmi),” J. Ilm. Media Eng., vol. 4, no. 2, pp. 109-118, Sep. 2014.

[3] Y. Simamora, "Analisis Risiko pada Instalasi Pengolahan Air Limbah (IPAL) PT. Ajinomoto Berdasarkan Konsep Manajemen Resiko Lingkungan,” Institut Teknologi Sepuluh Nopember, 2009.

[4] G. Vorley, Mini Guide to Root Cause Analysis. Guillford Surrey, UK: Quality Management \& Training Limited, 2008.

[5] Metcalf and Eddy, Wastewater Engineering Treatment And Resource Recovery. 5th edition. New York: Mc Graw Hill, 2014.

[6] G. M. Tillman, Water Treatment: Troubleshooting and Problem Solving. Washington, D.C: Lewis, 1996.

[7] R. E. Ambat and R. A. Prasetyo, "Perancangan bak sedimentasi,” Potensi J. Sipil Politek., vol. 17, no. 1, pp. 23-29, Mar. 2015.

[8] D. R. K. Hartaja and I. Setiadi, "Perencanaan desain instalasi pengolahan limbah industri nata de coco dengan proses lumpur aktif,” J. Rekayasa Lingkung., vol. 9, no. 2, pp. 97-112, 2016.

[9] F. A. Yanitra, "Evaluasi Kinerja Instalasi Pengolahan Air Limbah PT. Surabaya Industrial Estate Rungkut Management of Pasuruan Industrial Estate Rembang (PT. Sier - Pier)," Universitas Brawijaya, 1900. 